\title{
Ecological-Economic (Eco-Eco) Modelling in the River Basins of Mountainous Regions: Impact of Land Cover Changes on Sediment Yield in the Velicka Rijeka, Montenegro
}

\author{
Velibor SPALEVIC ${ }^{1}$, Milan LAKICEVIC ${ }^{2 *}$, Dragan RADANOVIC ${ }^{3}$, \\ Paolo BILLI ${ }^{4}$, Goran BAROVIC ${ }^{1}$, Dusko VUJACIC ${ }^{1}$, Paul SESTRAS ${ }^{5,6,7}$, \\ Abdulvahed KHALEDI DARVISHAN ${ }^{8}$ \\ ${ }^{1}$ University of Montenegro, Faculty of Philosophy, Geography Department, D. Bojovica, 81400 Niksic, \\ Montenegro; velibor.spalevic@ac.me;ff@ac.me;duskov@ac.me \\ ${ }^{2}$ University of Montenegro, Faculty of Economy, Podgorica, Montenegro; milanl@ac.me (*corresponding author) \\ ${ }^{3}$ Delegation of The European Union to Montenegro,Vuka Karadzica 12, Podgorica, Montenegro; dragan.radanovic@eeas.europa.eu \\ ${ }^{4}$ University of Tottori, International Platform for Dryland Research and Education, Japan; bli@unife.it \\ ${ }^{5}$ University of Agronomic Sciences and Veterinary Medicine Bucharest, Faculty of Land Reclamation and Environmental Engineering, \\ Department of Environment and Land Reclamation, 59 Mărăşti Blvd, District 1, 011464, Bucharest, Romania; paul.sestras@usamv.ro \\ ${ }^{6}$ Technical University of Cluj-Napoca, Faculty of Civil Engineering, Department of Terrestrial Measurement and Cadastre, \\ Baritiu St., 400027 Cluj-Napoca, Romania \\ ${ }^{7}$ University of Agricultural Sciences and Veterinary Medicine, 3-5 Manastur St., 400372 Cluj-Napoca, Romania \\ ${ }^{8}$ Tarbiat Modares University, Faculty of Natural Resources, Watershed Management, Iran; a.khaledi@modares.ac.ir
}

\begin{abstract}
This paper presents an Ecological-Economic (Eco-Eco) modelling using the Intensity of Erosion and Outflow (IntErO) model for calculation of sediment yield and runoff assessing the impacts of different land covers on soil erosion intensity. Calculations have been made for the Velicka River basin, which is one of 57 sub-basins of the Lim River in the Northeast Montenegro. Several different land use scenarios were then simulated in the model in order to find the optimal scenario of land use for intensive seed potato production. The results of Ecological (Eco-) analysis shown that the real soil loss under current conditions is $18148 \mathrm{~m}^{3} \mathrm{yr}^{-1}$. If seed potato production is introduced, the model calculated a soil loss of $20834 \mathrm{~m}^{3} \mathrm{yr}^{-1}$ as sediment yield. In order to balance the damage caused by the introduction of seed potato production we considered also the ecological measure of afforestation to reduce soil loss caused by seed potato production. The model calculated that afforestation would result in a decrease of sediment yield to $17886 \mathrm{~m}^{3} \mathrm{yr}^{-1}$. The results of Economic (-Eco) analysis revealed that the investment of $€ 3,385$ per ha for the establishment of the seed potato production will provide the income for the farmers of $€ 15,000$ per hectare annually. In parallel, we proposed the investment for the protection of the area $(258 \mathrm{ha})$ with afforestation that amounts to $€ 330,608$ ( $€ 1,281$ per ha), for the period of two years, with no other costs in the next decade. The research results demonstrate that the application of the Eco-Eco modelling, by using the IntErO model for studying the effect of soil erosion and possible land use for intensive seed potato production in the Velicka River Basin provides cost effective solutions for the benefit of the local population.
\end{abstract}

Keywords: Eco-Eco modelling, IntErO model, Soil erosion, Velicka River basin, Land cover

\section{Introduction}

In mountain areas such as the most part of Montenegro, watersheds are often affected by natural disasters including overflows, floods and inundations, erosion and landslides. Soil erosion is one of the most widespread and a major environmental threat which decreases agricultural productivity and affects water quality (Poesen et al., 1997; Weltzin et al., 2003; Nearing et al., 2005). There are several stages/types of water erosion, including splash, sheet, rill, gully and stream bank erosion (Toy et al., 2002; Poesen et al., 2003; Khaledi Darvishan et al., 2014 and 2015). Their 
negative effects on soil thickness and fertility, plant cover, runoff coefficient and flood risk may be remarkable, hence, soil erosion and sediment yield studies are of great interest in the world (especially in arid and semi-arid regions where soil and water resources are highly vulnerable. The widespread environmental impacts of soil erosion and loss are often not enough faced by the governments (Behzadfar et al., 2014).

Thus, the accurate understanding and quantification of soil erosion at watershed scale is essential to address many environmental problems influenced by the amount of sediment transported and deposited out of the basins. On the other hand, multi-years measurements of sediment transport at the watershed outlet may represent the soil loss in a watershed (Tazioli, 2009).

Multi-years measurements of sediment load transport at the watershed outlet represents the soil loss in a watershed (Tazioli, 2009) and can be used to calibrate soil erosion models (Tazioli, 2009; Khaledi Darvishan et al., 2010).

Modelling, when calibrated, are useful tools to test hypothesis and to evaluate the amount of discharge and erosion in a watershed, especially when hydrometric data are not available (Behzadfar et al., 2014). Therefore, erosion models have been developed to assess soil erosion and sediment yield, based on some simple empirical equations such as the Universal Soil Loss Equation (USLE), or some modified and updated versions of it (Wischmeier and Smith, 1965, 1978).

Since it is difficult to accurately measure soil erosion in the field, also the performance assessment of soil erosion models is difficult (Conoscenti et al., 2008, Rawat et al., 2011). By contrast, sediment yield models are easier to apply and to be tested, because the data for these models can be measured at the watershed outlet (Kinnell and Riss 1998; Erskine et al., 2002; Kinnell, 2010).

Among several models, Erosion Potential Method EPM, originally developed in Yugoslavia by Gavrilovic (1972), was in recent times repeatedly applied to watersheds in the Apennines and in the Balkan Peninsula (Stefanovic, 2004; Zorn and Komac, 2009; Milevski et al., 2008; Tazioli, 2009; Blinkov and Kostadinov, 2010; Ristic et al., 2012; Kostadinov et al., 2006, 2014; Spalevic et al., 2014a), but also in other regions in the world, for example in arid and semi-arid areas of the south-western USA (Gavrilovic, 1988), Saudi Arabia (Al-Turki et al., 2015). The method considers the main factors affecting erosion in a catchment, i.e. temperature, mean annual rainfall, soil use, geological properties and some other minor features of the catchment.

The Intensity of Erosion and Outflow model - IntErO program package (Spalevic, 2011), was developed to predict the intensity of soil erosion and the runoff peak discharge in a watershed. It is a computer-graphic method based on the Erosion Potential Method - EPM, which is embedded in its algorithm (Spalevic et al., 2013a).

The functions and processes of ecosystems are not easily characterized because of their complexity interrelation. There are some ecosystem characteristics which can be used to evaluate stress, such as runoff and sediment yield. Some ecosystems characteristics have obvious and immediate economic and/or human significance, while others appear important in a longer term or in more global sense (Bockstael et al., 1995). Though there are some considerable uncertainties regarding the relative significance of each characteristic (Bockstael et al., 1995), sediment yield can be used to show how land cover changes can affect soil erosion and, therefore, the ecological and economic conditions of a watershed. The importance of land cover changes on runoff, soil erosion and the economic conditions of the watershed has been rarely considered as one of the main anthropogenic effects. Land cover management is one of the main issues of sustainable development to design and implement reclamation measures especially in degraded areas (Ballesteros Cánovas et al., 2017).

Several studies addressed the interactions between ecological and economic functions in support of multiobjective policy making (e.g., Tschirhart and Crocker, 1987; Costanza et al., 1993; Bockstael et al., 1995; Johst et al., 2002; Pacini et al., 2004; Armstrong, 2007; Kleczkowski et al., 2015), whereas some other studies dealt with the utilization of advanced computer modeling and spatial data availability to address the transdisciplinary modeling task in new ways (e.g. Bockstael et al., 1995; Volk et al., 2008; Marta-Costa et al., 2013; Cordier et al., 2017; Zessner et al., 2017).

The objective of this paper is to apply ecologicaleconomic modeling by using the IntErO computer graphic model to predict soil erosion scenarios associated with intensive seed potato production at the Velicka Rijeka River Basin in the Northeast Mountainous region in Montenegro. This study aims also to emphasize how ecological-economic modelling approach may contribute to provide policy makers with scientifically based information for best practice decision making in various fields. Namely, it examines ecological aspects of soil erosion and economic development of areas affected by soil erosion processes and proposes measures to overcome these issues.

\section{Materials and Methods}

\section{Research area}

The river basin of the Velicka Rijeka is the right-hand tributary of the river Lim in the Northeast Montenegro. This basin covers a surface area of $32.2 \mathrm{~km}^{2}$ encompassing the villages of Velika, Volujak and Radevic. It is located 5.3 $\mathrm{km}$ north of Plav; $9 \mathrm{~km}$ south of Sekular, settlement of Spalevici; $15 \mathrm{~km}$ south-east of Andrijevica (Fig. 1).

The catchment slopes are very steep all the way from the Prijedolska glava (Hmax, $2077 \mathrm{~m}$ asl) to the confluence of the Velicka Rijeka into the Lim River (H min $879 \mathrm{~m}$ asl) for a distance of $5.20 \mathrm{~km}$. The length of the main watercourse is $6.9 \mathrm{~km}$. The shortest distance between the source and the mouth is $5.4 \mathrm{~km}$; length of the basin, measured with a series of parallel lines, $\mathrm{Lb}$, is $8.9 \mathrm{~km}$. Average altitude of the catchment is $1455.83 \mathrm{~m}$ asl, and the average height difference is $576.83 \mathrm{~m}$.

Satellite imagery, available from the Google Earth and Google Maps, were used to estimate standard morphometric methods (Spalevic et al., 2014b) and analyze the erosion rills density and the depth of the erosion base, to measure specific lengths such as the natural length of the main watercourse and tributaries of $1^{\text {st }}$ and $2^{\text {nd }}$ class, the length of the watershed and other physical-geographical characteristics. 
604

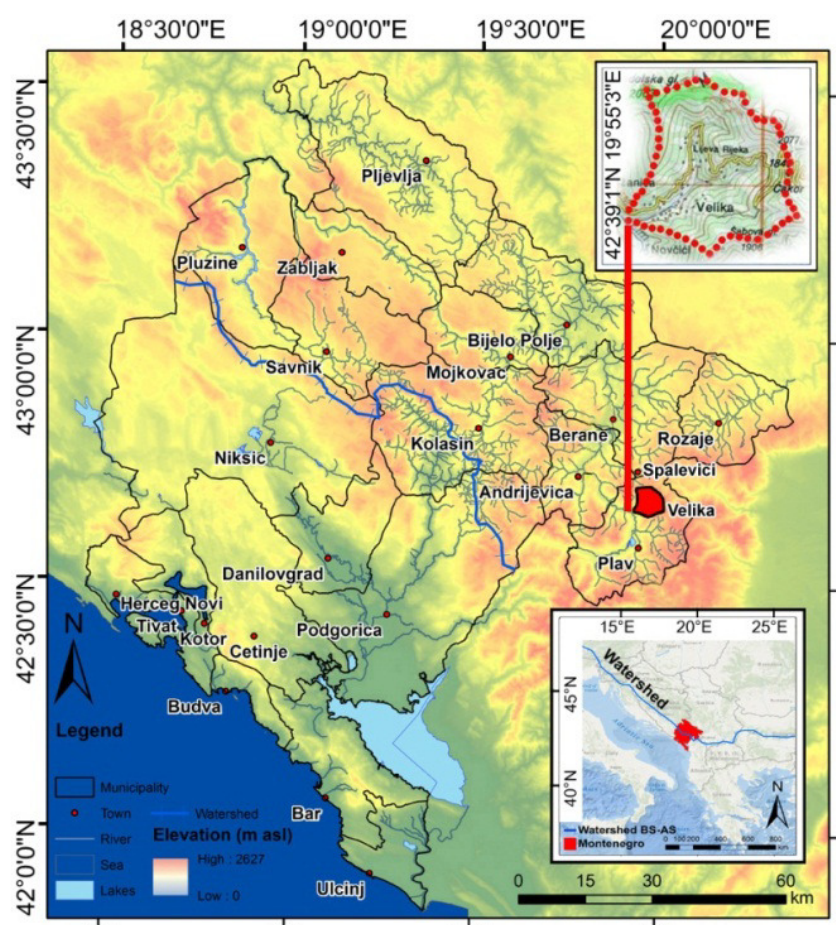

Fig. 1. Location map of the Velicka Rijeka River Basin

The research part related to geology and soil is based on previous geological (Zivaljevic, 1989) and pedological studies (Fustic and Djuretic, 2000), who analyzed all geological formations and soils of Montenegro. Furthermore, we collected some soil samples for chemical and physical analysis. The grain size composition of the soil was determined by the pipette method. The soil samples were air-dried at $105^{\circ} \mathrm{C}$ sifted through $2 \mathrm{~mm}$ sieve and dispersed using sodium pyrophosphate. Total carbonates were determined by the volumetric Scheibler method; the soil reaction ( $\mathrm{pH}$ in $\mathrm{H}_{2} \mathrm{O}$ and $\mathrm{nKCl}$ ) was determined with a potentiometer; the content of the total organic matter was determined by the Kotzman method; easily accessible phosphorous and potassium were determined by the Almethod and the adsorptive complex (y1, S, T, V) was determined by the Kappen method (Spalevic et al., 2013b).

We used IntErO model (www.agricultforest.ac. me/Spalevic/IntErO), based on Erosion Potential Method - EPM (Gavrilovic, 1972) and designed to assess annual erosion rates:

$$
\begin{aligned}
& W_{a}=T \times P_{a} \times \pi \sqrt{Z^{3} \times F} \quad T=\sqrt{\frac{T_{0}}{10}}+0.1 \quad Z=Y \times X_{a} \times\left(\phi+\sqrt{J_{a}}\right) \\
& \begin{array}{|l|l|l|}
\hline \xi=\frac{\sqrt{O \times Z}}{\left(I_{p}+10\right)} \times D_{d} & D_{d, \text { original }}=\frac{1}{0.25}=4 & G_{y}=\xi \times W_{a} \\
\hline
\end{array}
\end{aligned}
$$

where: Wa - Total annual volume of detached soil $\left[\mathrm{m}^{3} \mathrm{yr}^{-1}\right]$; $\mathrm{T}$ - Temperature coefficient [-]; $\mathrm{Pa}$ - Average annual precipitation [mm]; Z - Erosion coefficient [-]; F - Study area $\left[\mathrm{km}^{2}\right]$; T0 - Average annual temperature $\left[{ }^{\circ} \mathrm{C}\right]$; Y - Soil erodibility coefficient [-]; Xa - Soil protection coefficient [-]; $\phi$ - Coefficient of type and extent of erosion [-]; Ja - Average slope of the study area [\%]; $\xi$ - Sediment delivery ratio [-]; O - Perimeter of the watershed $[\mathrm{km}] ; \mathrm{z}$ - Mean difference in elevation of the watershed $[\mathrm{km}]$; Dd - Drainage density $[\mathrm{km}$ $\left.\mathrm{km}^{-2}\right]$; lp - Length of the principal waterway [km]; la Cumulated length of secondary waterways $[\mathrm{km}] ; \mathrm{L}$ Cumulated length of the principal and secondary waterways $[\mathrm{km}] ; \mathrm{Gy}$ - Actual sediment yield $\left[\mathrm{m}^{3} \mathrm{yr}^{-1}\right]$.

EPM is widely used in the Balkan Region because of its relative simplicity and it is preferred as a local model for calculation of soil erosion intensity for the territory of ExYugoslavia (Spalevic et al., 2013c). The use of EPM, including the River Basin model, has been used widely in Montenegro, especially in the Region of Polimlje (Spalevic et al., 2014b), representing a standardized approach.

In comparison with some other procedures, the EPM/IntErO model does not explore the physics of erosion processes; therefore, it is suitable for areas where basic data are available, or where there is a lack of previous erosion research. As such, the model can provide not only the amount of sediment yield, but also the erosion intensity as a preliminary result and indications or areas of potential erosion threats (Dragicevic et al., 2016).

\section{Climatic characteristics}

The effects of climate have the high impacts on land degradation; rainfalls and torrential rains are amongst the main triggers of soil erosion processes. Global warming is leading to a more vigorous hydrological cycle, including higher total precipitation and more frequent high intensity rainfall events. Rainfall amounts and intensities increased around the world during the $20^{\text {th }}$ century, and according to climate change models they are expected to continue to increase during the $21^{\text {st }}$ century (Nearing et al., 2004). These rainfall changes, along with expected changes in temperature have significant impacts on soil erosion rates.

Montenegro is experiencing increasing temperatures and evapotranspiration, most notably in the northern mountainous region. The 2001-2010 decade was the warmest since records began, with the most prominent changes in the northern mountainous region of $+1.4^{\circ} \mathrm{C}$ and with a decrease in the number of frost days and very cold days and nights. Changing rainfall pattern is also forecasted in the near future (more precipitations in winter, less in summer) increasing erosion, flood risk (winter) and water stress (summer). The analysis of the climatic patterns undertaken confirmed that climate in Montenegro has already changed and that the main impacts foreseen for temperatures and extreme events are confirmed (Froslev Christensen and Spalevic, 2017).

Regarding rainfall there has been no significant reduction in the average annual precipitation: rainfall has increased in autumn whereas it has decreased during spring, summer and winter. However, there has been a damaging and significant increase in the number of extreme weather events. This pertains especially to heat waves, that are increasingly frequent, and their length shows a high year-toyear variability. Secondly, but equally important, storms have become more frequent and more intense since 1998, resulting in huge amounts of precipitation and high flooding.

Extreme whether events (e.g. droughts, flooding and heatwaves) are increasingly impacting natural resources (soils, water bodies, pastures, others). Moreover, heavy snowfalls and flash floods are becoming more common. 
For this research we have used the data provided by the Institute of Hydrometeorology of Montenegro as well as calculations used in previous research papers (Spalevic et al., 2013a). The Velicka Rijeka catchment has a continental climate, with rainy autumns and springs and cold winters. The absolute air temperatures recorded range from a minimum of $-29.8{ }^{\circ} \mathrm{C}$ up to $35^{\circ} \mathrm{C}$. On the basis of the available data, the average annual air temperature, $t_{0}$, is $8.1^{\circ} \mathrm{C}$; average annual precipitation is $1182.3 \mathrm{~mm}$. Calculated temperature coefficient for this area, $\mathrm{T}$, is 0.95 ; the torrential rain, hb, is calculated to be $89.4 \mathrm{~mm}$.

\section{Geological structure}

Mountains in Montenegro are part of the Dinaric Alps. The terrain around the study area consists of various types of sedimentary, magmatic and metamorphic rocks, ranging in age from Palaeozoic to Quaternary. Most of the study area is underlain by Mesozoic formations of carbonate composition, while magmatic and clastic silicate rocks are significantly less present. Using the Geological map of Montenegro (Zivaljevic, 1989), permeability of the rocks of the study river basin has been defined. The coefficient of the region permeability, $\mathrm{S} 1$, is calculated to be 0.9 . Rocks of poor permeability (class fo) cover $79 \%$ of the study river basin area, very permeable rocks (class fp) cover $13 \%$ of the territory and semi-permeable rocks (class fpp) only $8 \%$.

\section{Soils of the area}

Prevailing soils in Montenegro are characterized by limited to low fertility ( $90 \%$ of soils), acid reaction ( $95 \%$ of soils in Montenegro are naturally acidic), often skeletal and shallow, with small retention capacity for moisture and nutrients. On the basis of both previous pedological results (Fustic and Djuretic, 2000) and original field and laboratory research, the most important types of soil in the basin are listed according to the percentage distribution: Dystric Cambisols (83.68\%), Eutric Cambisols (12.60\%), Kalkomelanosols (3.01\%), and traces of Fluvisols and Colluvial Fluvisols (0.71\%).

\section{Vegetation}

The study area belongs to the Dinaridi Province of the Middle-Southern-East European mountainous biogeographical region (Dees et al., 2013). Some wooded areas are found at higher altitudes in the Velicka river basin and on the top of Cakor mountain and its slopes, where forests of spruce (Picea abies), one of the most important tree species from Europe, are found. At Djevojacki krs, towards to the Sabova glava, the basin is covered by forests of Macedonian pine (Pinus peuce), and on the steep slopes towards the village of Velika, the forests of fir (Abies alba) and spruce (Picea abies) are prevailing. To the right side of the basin, around the rural community of Radevici, the beech forests (Fagetum montanum) have been gradually replaced by pastures. In the lower parts of the study river basin, at the confluence of the Velicka Rijeka into the Lim River, mixed forests of beech (Fagetum montanum) and oak (Quercus cerris) are present. In the lower parts, near the river bed, we recorded some hydrophilic forest (Alnetea glutinosae, Salicetea herbacea) and, subordinately, some Betula verrucosa, Quercus cerris, Quercus petraea and Prunus avium.

\section{Model parameters calculation}

The coefficient of vegetation cover, S2, was calculated to be 0.73 ; the coefficient of the river basin planning, $\mathrm{Xa}, 0.42$. According to the analysis of available data, meadows, pastures and orchards cover around 59\% of the study river basin. Mountain pastures are the most widespread vegetation cover (44.82\%). Meadows cover $12.95 \%$, orchards $1 \%$. Forests are covering 39\%: well-constituted forests $(30.18 \%)$ and degraded forests $(9.06 \%)$. Arable and cultivated land less than $2 \%$.

\section{Results and Discussion}

In order to carry out model verification for the study area, sediment yields were calculated for all the tributaries of the Lim river basins, which include the Velicka river basin. The model results were then compared with the measurements obtained at the Potpec reservoir. Using the Model the sediment yield was calculated to be 347273 $\mathrm{m}^{3}$ year $^{-1}$; while actual geodetically performed measurements were $350000 \mathrm{~m}^{3} \mathrm{year}^{-1}$. This validates calculations of the results for sediment yield obtained by the model. This leads to a conclusion that the model is applicable for the observed area (Spalevic et al., 2016).

In Italy, using the same methodology, Tazioli (2009) found that this model corresponds well concerning annual sediment yield using nuclear probes for suspended-load measurements on Musone and Esino watersheds. Similar studies were applied earlier at the Prescudin catchment in Italy, (Bemporad et al., 1997) recording a minimum deviation between predicted and measured sediment yield values. At the Bregalnica basin in Macedonia (Milevski et al., 2008), a very good match has been achieved between the results obtained using the EPM method and onsite measurements. It should be highlighted that the EPM/IntErO model considers the total sediment load, whereas most of the measurements conducted in the studies cited take into account suspended load only.

\section{Establishment of seed potato production and afforestation} as a measure of soil conservation

We have introduced eco-eco modeling in this research with the main idea to guide the farmers on how to get economic benefits, while respecting at the same time sustainable river basin management. Economic part of the main research hypothesis is that commercial production of seed potato will increase income of farmers, income of the state (by increase of collected taxes) and improve the state balance of payments by reducing the import of food (Montenegro produces approximately $18 \%$ of food that is consumed in the country). The increase of income will improve living standard and quality of life in the study catchment, thus reducing migration from this area.

The study river basin is suitable for growing potatoes. Most farmers produce vegetables for home consumption, because of higher value crop opportunities which exist due to the particular comparative advantage of this area. Farmland at $+800 \mathrm{~m}$ above sea level is ideal for producing high quality seed potato given the clean, virus free, low disease conditions. In an environment where no fruit can be cultivated above $1,300 \mathrm{~m}$ asl, highland varieties of potato are an important resource for certain households in the study 
606

area - on a commercial basis. For the establishment of intensive agricultural production it is important to improve land preparation, together with fertilizers and manure usage that will increase yields by one-third.

At the initial phase we proposed an expansion of the potato cultivated area that brings increased income and also incurs various production costs as well as cost of nature conservation of the study basin. For the purposes of this research we have taken into account theoretically maximum possible area of $2.58 \mathrm{~km}^{2}$ (258 ha) for establishment of an intensive agricultural production at this territory. This area extends on a $5 \mathrm{~km}$ long course within the territory of village Velika, the valley across the Papratista and Lijeva Rijeka to the village Radevic. In real terms it would be hardly feasible for the agricultural production to be implemented on the entire territory mentioned above, due to property issues, labor shortages and other issues. We decided to prove our concept using simple calculation in accordance with potentials of the nature in the observed area.

However, establishing intensive potato production causes environmental damage by increasing the soil erosion intensity, which can be balanced by the introduction of conservation pathways. In order to calculate these economic benefits, we used the IntErO model to calculate soil erosion and its repercussion on the potato farming economic system. Calculation of seed potato production costs per 1 hectare for the region of Velicka river basin is presented in the Table 1.

Table 1. Calculation of seed potato production costs per hectare for the Velicka river basin

\begin{tabular}{|c|c|c|}
\hline $\mathbf{A}$ & Production operation & Cost per operation per ha in $€$ \\
\hline 1 & Ploughing & 100 \\
\hline 2 & Transportation of mineral fertilizers & 5 \\
\hline 3 & Distribution of mineral fertilizers & 5 \\
\hline 4 & Land Planning & 50 \\
\hline 5 & Transport of seed potatoes & 10 \\
\hline 6 & Planting potatoes & 50 \\
\hline 7 & Covering potatoes by soil & 20 \\
\hline 8 & Treatment against weeds & 10 \\
\hline 9 & Treatment of diseases and pests ( 3 times) & 30 \\
\hline 10 & Extraction of potatoes & 100 \\
\hline \multirow[t]{2}{*}{11} & Transport of potato to the warehouse & 120 \\
\hline & Total & 500 \\
\hline $\mathbf{B}$ & Raw materials & Cost of material per ha in $€$ \\
\hline 1 & Potato seed & 1200 \\
\hline 2 & Fertilizer NPK & 500 \\
\hline 3 & Fertilizer KAN & 60 \\
\hline 4 & Herbicides & 75 \\
\hline 5 & Insecticides & 100 \\
\hline 6 & Fungicides & 160 \\
\hline \multirow[t]{2}{*}{8} & Bags & 150 \\
\hline & Total & 2245 \\
\hline C & Labor & Cost for labor per ha in $€$ \\
\hline 1 & Potting of potatoes & 20 \\
\hline 2 & Loading - unloading fertilizers & 10 \\
\hline 3 & Spreading of fertilizers & 10 \\
\hline 4 & Loading - unloading of potatoes & 20 \\
\hline 5 & Seeding of potato & 40 \\
\hline 7 & Weeding weeds & 20 \\
\hline 8 & Treatment against diseases and pests & 20 \\
\hline 9 & Extraction of potatoes & 400 \\
\hline \multirow[t]{2}{*}{10} & Loading - unloading of potatoes & 100 \\
\hline & Total & 640 \\
\hline
\end{tabular}

Total costs $\mathrm{A}+\mathrm{B}+\mathrm{C}=3,385(€)$

\begin{tabular}{ccc}
\hline D & Results & Component in $€$ per ha \\
\hline 1 & Total cost & 3,385 \\
2 & Expected yield & $30,000 \mathrm{~kg} \mathrm{ha}^{-1}$ \\
3 & Cost of production & $0.113 € \mathrm{~kg}^{-1}$ \\
4 & Seed potato market price (2017 local market price) & $0.50 € \mathrm{~kg}^{-1}$ \\
5 & Market value of product & $15,000 €$ \\
6 & VAT (7\%) & $981 €$ \\
7 & Realized profit (5-1) & $11,610 €$ \\
\hline
\end{tabular}


In order to calculate costs and income of seed potato production we have quantified the following costs: production operations costs, raw material costs and labor costs. In agreement with Article 24 of Montenegrin VAT Law, VAT rate for seed potato is 7\%; however, we did not examine in detail taxation issues in order to not overcomplicate the model.

Taking into account that the study area is 258 ha and the calculated profit per hectare (see table 1d) is $€ 10,629$, this adds to the total profit of $€ 2,742,282$ annually. This amounts to a total nominal profit of $€ 27,422,820$ for the next decade (without taking into account price changes and time value of money), which is the basic time frame for calculation of afforestation costs in this research paper (Table 2).

The model has taken into account all of the above parameters (27 input data and 22 results) (Table 4 ) and it was calculated that the real soil loss under current conditions is $18,148 \mathrm{~m}^{3} \mathrm{yr}^{-1}$. If seed potato production is introduced, the model calculated a soil loss of $20,834 \mathrm{~m}^{3} \mathrm{yr}^{-1}$ as sediment yield. In order to balance the damage caused by the introduction of seed potato production we considered also the ecological measure of afforestation to reduce soil loss caused by seed potato production. The model calculated that afforestation would result in a decrease of sediment yield to $17,886 \mathrm{~m}^{3} \mathrm{yr}^{-1}$. The outcomes of model calculation are presented in Fig. 2.

From these results the twofold benefit of introducing the potato production coupled with afforestation is evident. On the one side, we have an increase in the farmer income and on the other side with planting the new areas under the forest a significant environmental improvement is achieved.

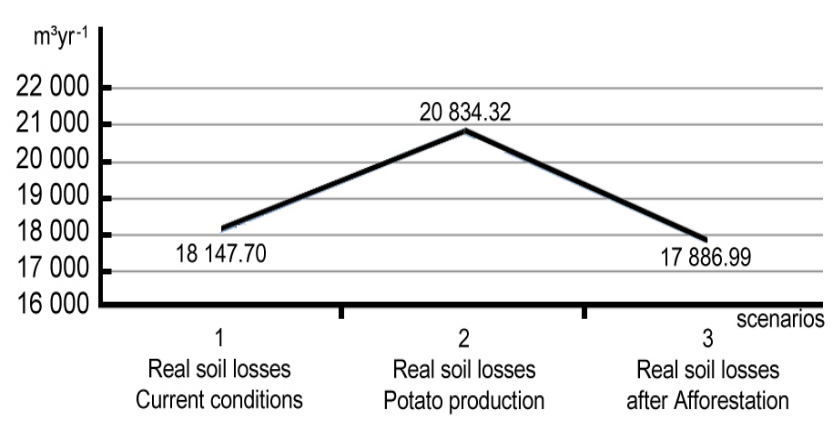

Fig. 2. Real soil losses $\left(\mathrm{m}^{3} \mathrm{yr}^{-1}\right)$ : initial (1), under the seed potato production (2), under the seed potato production after the afforestation (3)

Table 2. Calculation of afforestation costs for studied area (invested in first 2 years)

\begin{tabular}{|c|c|c|}
\hline 1 & Type of terrain & Pasture and barefoot \\
\hline 2 & Conservation measure & Digging holes with planting \\
\hline 3 & Excavation with planting ( $€ / 8$ working hours $)$ & 15 \\
\hline 4 & Normative (pieces/8 working hours) & 70 \\
\hline 5 & Number of pieces per ha & 2500 \\
\hline 6 & Price of spruce seedlings ( $€ /$ piece $)$ & 0.18 \\
\hline 7 & Basic planting per hectare $(€)$ & 985.71 \\
\hline 8 & Filling charges for 2 years $(€)$ & 295.71 \\
\hline 9 & Reforestation costs per hectare $(€)$ & $1,281.43$ \\
\hline 10 & Reforestation area $(\mathrm{ha})$ & 258 \\
\hline 11 & Total costs for the studied area $(9 \mathrm{x} 10, €)$ & $330,608.94$ \\
\hline
\end{tabular}

Table 3. Land use changes in the studied river basin of the Velicka Rijeka

\begin{tabular}{|c|c|c|c|c|c|}
\hline Land use & Symbol & $\begin{array}{c}\text { Initial } \\
(1)\end{array}$ & $\begin{array}{c}\text { Potato } \\
(2)\end{array}$ & $\begin{array}{c}\text { Forest } \\
(3)\end{array}$ & Units \\
\hline Bare lands: & $\mathrm{BL}$ & 0 & 0 & 0 & $\%$ \\
\hline Plough-lands: & $\mathrm{P}$ & 1.99 & 9.99 & 9.99 & $\%$ \\
\hline Orchards: & $\mathrm{O}$ & 1.00 & 1.00 & 1.00 & $\%$ \\
\hline Mountain pastures: & MP & 44.82 & 44.82 & 44.82 & $\%$ \\
\hline Meadows: & M & 12.95 & 4.95 & 4.95 & $\%$ \\
\hline Degraded forests: & DF & 9.06 & 9.06 & 1.06 & $\%$ \\
\hline \multirow[t]{2}{*}{ Well-constituted forests: } & WF & 30.18 & 30.18 & 38.18 & $\%$ \\
\hline & Total & 100 & 100 & 100 & $\%$ \\
\hline Bare lands: & $\mathrm{BL}$ & 0.00 & 0.00 & 0.00 & $\mathrm{~km}^{2}$ \\
\hline Plough-lands: & $\mathrm{P}$ & 0.64 & 3.22 & 3.22 & $\mathrm{~km}^{2}$ \\
\hline Orchards: & $\mathrm{O}$ & 0.32 & 0.32 & 0.32 & $\mathrm{~km}^{2}$ \\
\hline Mountain pastures: & $\mathrm{MP}$ & 14.46 & 14.46 & 14.46 & $\mathrm{~km}^{2}$ \\
\hline Meadows: & M & 4.18 & 1.60 & 1.60 & $\mathrm{~km}^{2}$ \\
\hline Degraded forests: & DF & 2.92 & 2.92 & 0.34 & $\mathrm{~km}^{2}$ \\
\hline \multirow[t]{2}{*}{ Well-constituted forests: } & WF & 9.74 & 9.74 & 12.32 & $\mathrm{~km}^{2}$ \\
\hline & Total & 32.26 & 32.26 & 32.26 & $\mathrm{~km}^{2}$ \\
\hline
\end{tabular}


608

Table 4. The detailed calculation of the "IntErO" model for the Velicka Rijeka watershed

\begin{tabular}{|c|c|c|c|c|c|}
\hline & Symbol & $\begin{array}{c}\text { Initial } \\
(\mathbf{1})\end{array}$ & $\begin{array}{c}\text { Potato } \\
\text { (2) }\end{array}$ & $\begin{array}{c}\text { Forest } \\
(3)\end{array}$ & Units \\
\hline \multicolumn{6}{|c|}{ Inputs for calculation of sediment yield } \\
\hline River basin area & $\mathrm{F}$ & 32.26 & 32.26 & 32.26 & $\mathrm{~km}^{2}$ \\
\hline The length of the watershed & $\mathrm{O}$ & 24.31 & 24.31 & 24.31 & $\mathrm{~km}$ \\
\hline Natural length watercourse & Lv & 6.91 & 6.91 & 6.91 & $\mathrm{~km}$ \\
\hline The distance: fountainhead - mouth & $\mathrm{Lm}$ & 5.44 & 5.44 & 5.44 & $\mathrm{~km}$ \\
\hline Length of watercourse with tributaries & $\Sigma \mathrm{L}$ & 10.18 & 10.18 & 10.18 & $\mathrm{~km}$ \\
\hline RB length: by a series of parallel lines & $\mathrm{Lb}$ & 8.89 & 8.89 & 8.89 & $\mathrm{~km}$ \\
\hline The area of the bigger river basin part & $\mathrm{Fv}$ & 19.92 & 19.92 & 19.92 & $\mathrm{~km}^{2}$ \\
\hline The area of the smaller river basin part & $\mathrm{Fm}$ & 12.33 & 12.33 & 12.33 & $\mathrm{~km}^{2}$ \\
\hline Altitude of the first contour line & h0 & 900 & 900 & 900 & $\mathrm{~m}$ \\
\hline The lowest river basin elevation & Hmin & 879 & 879 & 879 & $\mathrm{~m}$ \\
\hline The highest river basin elevation & Hmax & 2077 & 2077 & 2077 & $\mathrm{~m}$ \\
\hline Very permeable products from rocks & $\mathrm{fp}$ & 0.13 & 0.13 & 0.13 & \\
\hline Part with medium permeable rocks & fpp & 0.08 & 0.08 & 0.08 & \\
\hline Part of poor water permeability rocks & fo & 0.79 & 0.79 & 0.79 & \\
\hline Part of the river basin under forests & fś & 0.39 & 0.39 & 0.39 & \\
\hline A part under grass and orchards & $\mathrm{ft}$ & 0.59 & 0.51 & 0.51 & \\
\hline Plough-land, without grass & fg & 0.02 & 0.10 & 0.10 & \\
\hline The volume of the torrent rain & $\mathrm{hb}$ & 89.4 & 89.4 & 89.4 & $\mathrm{~mm}$ \\
\hline Average annual air temperature & $\mathrm{t} 0$ & 8.1 & 8.1 & 8.1 & ${ }^{\circ} \mathrm{C}$ \\
\hline Average annual precipitation & Hyr & 1182.3 & 1182.3 & 1182.3 & $\mathrm{~mm}$ \\
\hline Types of soil products, related types & $\mathrm{Y}$ & 1.1 & 1.1 & 1.1 & \\
\hline Coefficient of the basin planning & $\mathrm{Xa}$ & 0.42 & 0.46 & 0.41 & \\
\hline Equivalents clearly exposed erosion & $\phi$ & 0.46 & 0.46 & 0.46 & \\
\hline \multicolumn{6}{|l|}{ Results } \\
\hline Coefficient of the river basin form & $\mathrm{A}$ & 0.69 & 0.69 & 0.69 & \\
\hline Coefficient of watershed development & $\mathrm{m}$ & 0.34 & 0.34 & 0.34 & \\
\hline Average river basin width & B & 3.63 & 3.63 & 3.63 & $\mathrm{~km}$ \\
\hline (A)symmetry of the river basin & $\mathrm{a}$ & 0.47 & 0.47 & 0.47 & \\
\hline Density of the river network & G & 0.32 & 0.32 & 0.32 & \\
\hline Coefficient of the basin tortuousness & $\mathrm{K}$ & 1.27 & 1.27 & 1.27 & \\
\hline Average river basin altitude & $\mathrm{Hsr}$ & 1455.8 & 1455.8 & 1455.8 & $\mathrm{~m}$ \\
\hline Average elevation difference & $\mathrm{D}$ & 576.8 & 576.8 & 576.8 & $\mathrm{~m}$ \\
\hline Average river basin decline & Isr & 40.81 & 40.81 & 40.81 & $\%$ \\
\hline Height of the local erosion base & Hleb & 1198 & 1198 & 1198 & $\mathrm{~m}$ \\
\hline Coefficient of erosion energy of relief & Er & 160.01 & 160.01 & 160.01 & \\
\hline Coefficient of region's permeability & S1 & 0.9 & 0.9 & 0.9 & \\
\hline Coefficient of the vegetation cover & S2 & 0.73 & 0.74 & 0.74 & \\
\hline Analytics of water retention in inflow & W & 1.0947 & 1.0947 & 1.0947 & $\mathrm{~m}$ \\
\hline Water-flow potential on torrent rains & $2 \mathrm{gDF}^{\wedge 1 / 2}$ & 604.22 & 604.22 & 604.22 & $\mathrm{~m} \mathrm{~km} \mathrm{~s}$ \\
\hline Maximal outflow from the basin & Qmax & 295.01 & 301.31 & 301.31 & $\mathrm{~m}^{3} \mathrm{~s}^{-1}$ \\
\hline Temperature coefficient of the region & $\mathrm{T}$ & 0.95 & 0.95 & 0.95 & \\
\hline Coefficient of the basin erosion & $\mathbf{Z}$ & 0.505 & 0.553 & 0.500 & \\
\hline Production of erosion material & Wyr & 40971 & 47034 & 40380 & $\mathrm{~m}^{3} \mathrm{yr}^{-1}$ \\
\hline Coefficient of the deposit retention & $\mathrm{Ru}$ & 0.443 & 0.443 & 0.443 & \\
\hline Real soil losses per $\mathrm{km}^{2}$ & $\mathrm{Gyr}_{\mathrm{km}}{ }^{2}$ & 562.6 & 645.86 & 554.49 & $\mathrm{~m}^{3} \mathrm{~km}^{2} \mathrm{yr}^{-1}$ \\
\hline
\end{tabular}

\section{Conclusions}

Several different land use scenarios were simulated using the IntErO model in order to find the optimal scenario of land use for intensive seed potato production in the Velicka Rijeka in Montenegro. The main points of research are the interactions between seed potato production, as an intense agricultural/economic activity, and afforestation, as a wellknown soil and water conservation activity. It can be simply concluded that agriculture can be used more conservatively with afforestation and, as a kind of agro-forestry, has the ability to decrease even soil loss in the study area. The effects of afforestation on various variables such as soil physical, chemical and biological characteristics, water infiltration, runoff and soil loss and etc. have been already proven in previous studies but the interaction effect between afforestation and seed potato production especially in soil loss was studied and proved in present research. The abilities of IntErO to simply investigate the effect of various scenarios of land use change made lots of such studies possible without doing any changes in the actual land uses. This advantage can be a very important tool on the working table of managers and policy planners. The quantitative results of soil loss in studied scenarios also showed that 
afforestation can compensate the increasing effect of seed potato production on soil loss. In other word, seed potato production increased soil loss by $15 \%$, while seed potato production after afforestation decreased it again by even more than the same rate.

There is another important point about the type of agricultural activities as well as the species of trees used for afforestation in each study area and should be taken into account. Technical notes of planting the selected tree species such as the distance and network dimensions and similar can play a very important role in the final ecologicaleconomic (Eco-Eco) modelling and results.

\section{References}

Al-Turki AM, Ibrahim HM, Spalevic V (2015). Impact of land use changes on soil erosion intensity in Wadi Jazan watershed in southwestern Saudi Arabia. Agrosym 2015, Jahorina, Bosnia and Herzegovina 2015:10.

Armstrong C (2007). A note on the ecological-economic modelling of marine reserves in fisheries. Ecological Economics 62:242-250.

Ballesteros Cánovas JB, Stoffel M, Martín-Duque JF, Corona C, Lucía A, Bodoque JM Montgomery DR (2017). Gully evolution and geomorphic adjustments of badlands to reforestation. Scientific Reports 7:45027.

Behzadfar M, Tazioli A, Vukelic-Shutoska M, Simunic I, Spalevic V (2014). Calculation of sediment yield in the S1-1 Watershed, Shirindareh Watershed, Iran. Agriculture and Forestry 60(4):207-216.

Bemporad GA, Alterach J, Amighetti FF, Peviani M, Saccardo I (1997). A distributed approach for sediment yield evaluation in Alpine regions. Journal of Hydrology 197(1-4):370-392

Blinkov I, Kostadinov S (2010). Applicability of various erosion risk assessment methods for engineering purposes. BALWOIS 2010 Conference, Ohrid, Macedonia, 25-29 May 2010.

Bockstael N, Costanza R, Strand I, Boynton W, Bell K, Wainger L (1995). Ecological economic modeling and valuation of ecosystems. Ecological Economics 14:143-159.

Conoscenti C, Di Maggio C, Rotigliano E (2008). Soil erosion susceptibility assessment and validation using a geostatistical multivariate approach: a test in Southern Sicily. Natural Hazards 46(3):287-305.

Cordier M, Uehara T, Weih J, Hamaide B (2017). An Input-output Economic Model Integrated within a System Dynamics Ecological Model: Feedback Loop Methodology Applied to Fish Nursery Restoration. Ecological Economics 140:46-57.

Costanza R, Wainger L, Folke C, Maler KG (1993). Modeling complex ecological economic systems: toward an evolutionary, dynamic understanding of people and nature. BioScience 43:545-555.

Dees M, Andjelic M, Fetic A, Jokanovic B, Tepavcevic V, Borota D, Vasiljevic A, Weinreih A, Hahn N, Markovic D, Terzic D (2013). The First National Forest Inventory of Montenegro. Ministry of Agriculture and Rural Development, Government of Montenegro, pp 347.

Dragicevic N, Karleusa B, Ozanic N (2016). A review of the Gavrilovic method (Erosion Potential Method) application. Gradjevinar 68(9):715-725.

Erskine WD, Mahmoudzadeh A, Myers C (2002). Land use effects on sediment yields and soil loss rates in small basins of Triassic Sandstone nearSydney, NSW, Australia. Catena 49:271-287.
Froslev Christensen P, Spalevic V (2017). Rural Clustering and Transformation Project (RCTP) - Final project design report. Project No. 2000001076, Report No: 4489-ME, Near East, North Africa and EuropeDivision, IFAD, Rome, pp 243.

Fustic B, Djuretic G (2000). Soils of Montenegro. Biotechnical institute, University of Montenegro.

GavrilovicS(1972).Inzenjeringo bujicnim tokovimai eroziji(Engineering of torrents erosion) (in Serbian). Izgradnja, Belgrade special edition.

JohstK, Drechsler M, WätzoldF (2002). An ecological-economic modelling procedure to design compensation payments for the efficient spatiotemporal allocation of species protection measures. Ecological Economics 41(1):37-49.

Kinnell PIA (2010). Event soil loss, runoff and the Universal Soil Loss Equation family of models: a review. Journal of Hydrology 385:384 397.

Kinnell PIA, Riss LM (1998). USLE-M: empirical modeling rainfall erosion through runoff and sediment concentration. Soil Science Society of America Journal 62:1662-1672.

Khaledi Darvishan A, Banasik K, Sadeghi SHR, Gholami L, Hejduk L (2015). Effects of rain intensity and initial soil moisture on hydrological responses in laboratory conditions. International Agrophisics 29:165173.

Khaledi Darvishan A, Sadeghi SHR, Homaee M, Arabkhedri M (2014). Measuring sheet erosion using synthetic color-contrast aggregates. Hydrological Processes 28(15):4463-4471.

Khaledi Darvishan A, Sadeghi SHR, Gholami L (2010). Efficacy of timearea method in simulating temporal variation of sediment yield in Chehelgazi Watershed, Iran. Annals of Warsaw University of Life Sciences $42(1): 51-60$.

Kleczkowski A, Ellis C, Goulson D, de Vries FP, Hanley N (2015). Ecological-economic modelling of interactions between wild and commercial bees and pesticide use. University of Stirling . Retrieved 2017 January 3 from http:/www.stir.ac.uk/management/research/ economics/working-papers/.

Kostadinov S, Zlatic M, Dragovic N, Gavrilovic Z (2006). Soil Erosion in Serbia and Montenegro. In: Boardman J, Poesen J (Eds). Soil Erosion in Europe.John Wiley \& Sons, Ltd London pp 271-277.

Kostadinov S, Zlatic M, Dragicevic S, Novkovic I, Kosanin O, Borisavljevic A, Lakicevic M, Mladjan D (2014). Anthropogenic influence on erosion intensity changes in the Rasina river watershed - Central Serbia. Fresenius Environmental Bulletin 23:254-263.

Marta-Costa AA, Manso F, Tibério L, Fonseca C (2013). Ecologicaleconomic modelling for farming systems of Montemuro Mountain (Portugal). In: Methods and Procedures for Building Sustainable Farming Systems. Springer Netherlands pp 207-217.

Milevski I, Blinkov I, Trendafilov A (2008). Soil erosion processes and modelling in the upper Bregalnica catchment. In: Proceedings of the conference of the Danubial countries on the hydrological forecasting and hydrological bases of water management (XXIV). Bled, Slovenia, pp 1-10.

Nearing MA, Pruski FF, O'Neal MR (2004). Expected climate change impacts on soil erosion rates: A review. Journal of Soil Water Conservation 59(1):43-50.

Nearing MA, Jetten V, Baffaut C, Cerdan O, Couturier A, Hernandez M, 
610

Le Bissonnais Y, Nichols MH, Nunes JP, Renschler CS, Souchère V, Van Oost K (2005). Modeling response of soil erosion and runoff to changes in precipitation and cover. Catena 61:131-154.

Pacini C, Wossink A, Giesen G, Huirne R (2004). Ecological-economic modelling to support multi-objective policy making: a farming systems approach implemented for Tuscany. Agriculture, Ecosystems \& Environment 102(3):349-364.

Poesen J, Nachtergaele J, Verstraeten G, Valentin C (2003). Gully erosion and environmental change: importance and research needs. Catena 50(2):91-133.

Poesen J, Hooke J (1997). Erosion, flooding and channel management in Mediterranean environments of southern Europe. Progress in Physical Geography 21(2):157-199.

Rawat PK, Tiwari PC, Pant CC, Sharama AK, Pant PD (2011). Modelling of stream run-off and sediment output for erosion hazard assessment in Lesser Himalaya: need for sustainable land use plan using remote sensing and GIS: a case study. Natural Hazards 59:1277-1297.

Ristic R, Kostadinov S, Abolmasov B, Dragicevic S, Trivan G, Radic B, Trifunovic M, Radosavljevic Z (2012). Torrential floods and town and country planning in Serbia. Natural Hazard and Earth System Sciences 12(1):23-35.

Spalevic V, Barovic G, Fikfak A, KosanovicS, Djurovic M, PopovicS (2016). Sediment yield and land use changes in the northern Montenegrin watersheds: Case study of Seocki Potok of the Polimlje. Journal of Environmental Protection and Ecology 17(3):990-1002.

Spalevic V, Hübl J, Hasenauer H, Curovic M (2014a). Calculation of soil erosion intensity in the Bosnjak Watershed, Polimlje River Basin, Montenegro. The 5th International Symposium "Agrosym 2014", Jahorina, 23-26October 2014, Bosnia and Herzegovina pp 730-738.

Spalevic V, Radanovic D, Behzadfar M, Djekovic V, Andjelkovic A, Milosevic N (2014b). Calculation of the sediment yield of the Trebacka Rijeka, Polimlje, Montenegro. Agriculture and Forestry 60(1):259-272.

Spalevic V, Djurovic N, Mijovic S, Vukelic-Sutoska M, Curovic M (2013a). Soil erosion intensity and runoff on the Djuricka River Basin (north of Montenegro). Malaysian Journal of Soil Science 17:49-68.

Spalevic V, Grbovic K, Gligorevic K, Curovic M, Billi P (2013b). Calculation of runoff and soil erosion on the Tifran watershed, Polimlje, North-East of Montenegro. Agriculture and Forestry 59(4):5-17.

Spalevic V, Nyssen J, Curovic M, Lenaerts T, Kerckhof A, Annys K, Van Den Branden J, Frankl A (2013c). The impact of land use on soil erosion in the river basin Boljanska Rijeka in Montenegro. In: Proceeding of the 4th International Symposium "Agrosym 2013", Jahorina, Bosnia pp 5463.
Spalevic V (2011). Impact of land use on runoff and soil erosion in Polimlje. Doctoral thesis, Faculty of Agriculture of the University of Belgrade, Serbia.

Stefanovic M, Gavrilovic Z, Milojevic M (2004). Erosion potential method and erosion risk zoning in mountainous regions. In: International Symposium Iterprevent-RIVA \TRIENT.

Tazioli A (2009). Evaluation of erosion in equipped basins: preliminary results of a comparison between the Gavrilovic model and direct measurements of sediment transport. Environmental Geology 56(5):825-831.

Toy TJ, Foster GR, Renard KG (2002). Soil Erosion: Processes, Prediction, Measurement, and Control.New York:John Wiley and Sons, pp 338.

Tschirhart J, Crocker TD (1987). Economic valuation of ecosystems. Transaction of the American Fisheries society 116(3):469-478.

Volk M, Hirschfeld J, Dehnhardt A, Schmidt G, Bohn C, Liersch S, Gassman PW (2008). Integrated ecological-economic modelling of water pollution abatement management options in the Upper Ems River Basin. Ecological Economics 66(1):66-76.

Weltzin JF, Loik ME, Schwinning S, Williams DG, Fay PA, Haddad BM, ... Zak JC (2003). Assessing the response of terrestrial ecosystems to potential changes in precipitation. Biosciences 53:941-952.

Wischmeier WH, Smith DD (1965). Predicting rainfall erosion losses from cropland east of the Rocky Mountains. Agriculture HandbookNo 282, USDepartment of Agriculture, Washington DC.

Wischmeier WH, Smith DD (1978). Predicting rainfall erosion losses. Agriculture Handbook No 537. Agriculture Research Service, US Department of Agriculture, Washington DC.

Zessner M, Schönhart M, Parajka J, Trautvetter H, Mitter H, Kirchner M, ... Schmid E (2017). A novel integrated modelling framework to assess the impacts of climate and socio-economic drivers on land use and water quality. Science of the Total Environment 579:1137-1151.

Zivaljevic M (1989). Geological Map of SR Montenegro, 1: 200.000.Special Edition, Geological gazette Book VIII, Titograd.

Zorn M, Komac B (2009). Response of soil erosion to land use change with particular reference to the last 200 years (Julian Alps, Western Slovenia). Revistade Geomorfologie 11:3947. 